UNC,LASSIFIED

CLASSIFICATION LEVEL

(S, C OR U)
$D R-0.827-3$

A. Ma PERRY
ATOMICS INTERNATIONAL

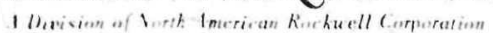

TENSIIE AND STRESS RUPTURE TESTS OF SBDR HASTELLOI-N

HEATS - ORNL VERIFICATION TESTS

NOTICE

THIS REPORT IS ILLEGIBLE TO A DEGREE

THAT PHECLUDES SATISFACTORY REPRODUCTION

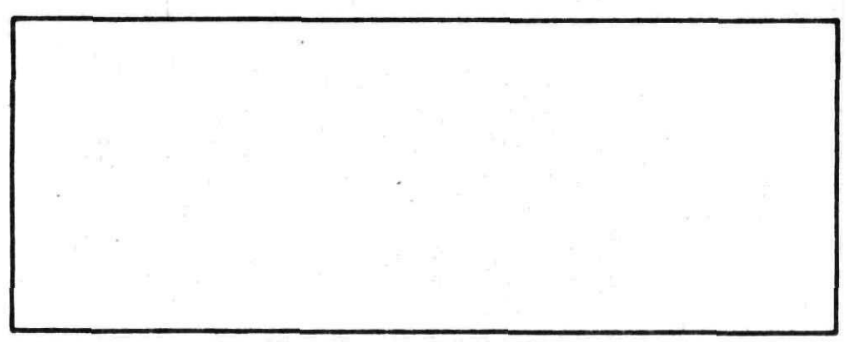

NAA-SR-TDR- -12550

\section{DE85 004473}

CLASSIFICATION TYPE

(RD OR DI)

'ed,

This report was prepared as an account of work sponsored by an agency of the United States Government. Neither the United States Government nor any agency thereof, nor any of their employees, makes any warranty, express or implied, or assumes any legal liability or responsibility for the accuracy, completeness, or usefulness of any information, apparatus, product, or process disclosed, or represents that its use would not infringe privately owned rights. Reference herein to any specific commercial product, process, or service by trade name, trademark, manufacturer, or otherwise does not necessarily constitute or imply its endorsement, recommendation, or favoring by the United States Government or any agency thereof. The views and opinions of authors expressed herein do not necessarily state or reflect those of the United States Government or any agency thereof.

IINCLASSIFIED

CLASSIFICATION LEVEL

(S, COR U)
OSTRRBUTION OF THIS DOCUMENT IS UNLIMITED

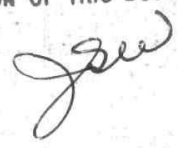




\section{DISCLAIMER}

This report was prepared as an account of work sponsored by an agency of the United States Government. Neither the United States Government nor any agency Thereof, nor any of their employees, makes any warranty, express or implied, or assumes any legal liability or responsibility for the accuracy, completeness, or usefulness of any information, apparatus, product, or process disclosed, or represents that its use would not infringe privately owned rights. Reference herein to any specific commercial product, process, or service by trade name, trademark, manufacturer, or otherwise does not necessarily constitute or imply its endorsement, recommendation, or favoring by the United States Government or any agency thereof. The views and opinions of authors expressed herein do not necessarily state or reflect those of the United States Government or any agency thereof. 


\section{DISCLAIMER}

Portions of this document may be illegible in electronic image products. Images are produced from the best available original document. 


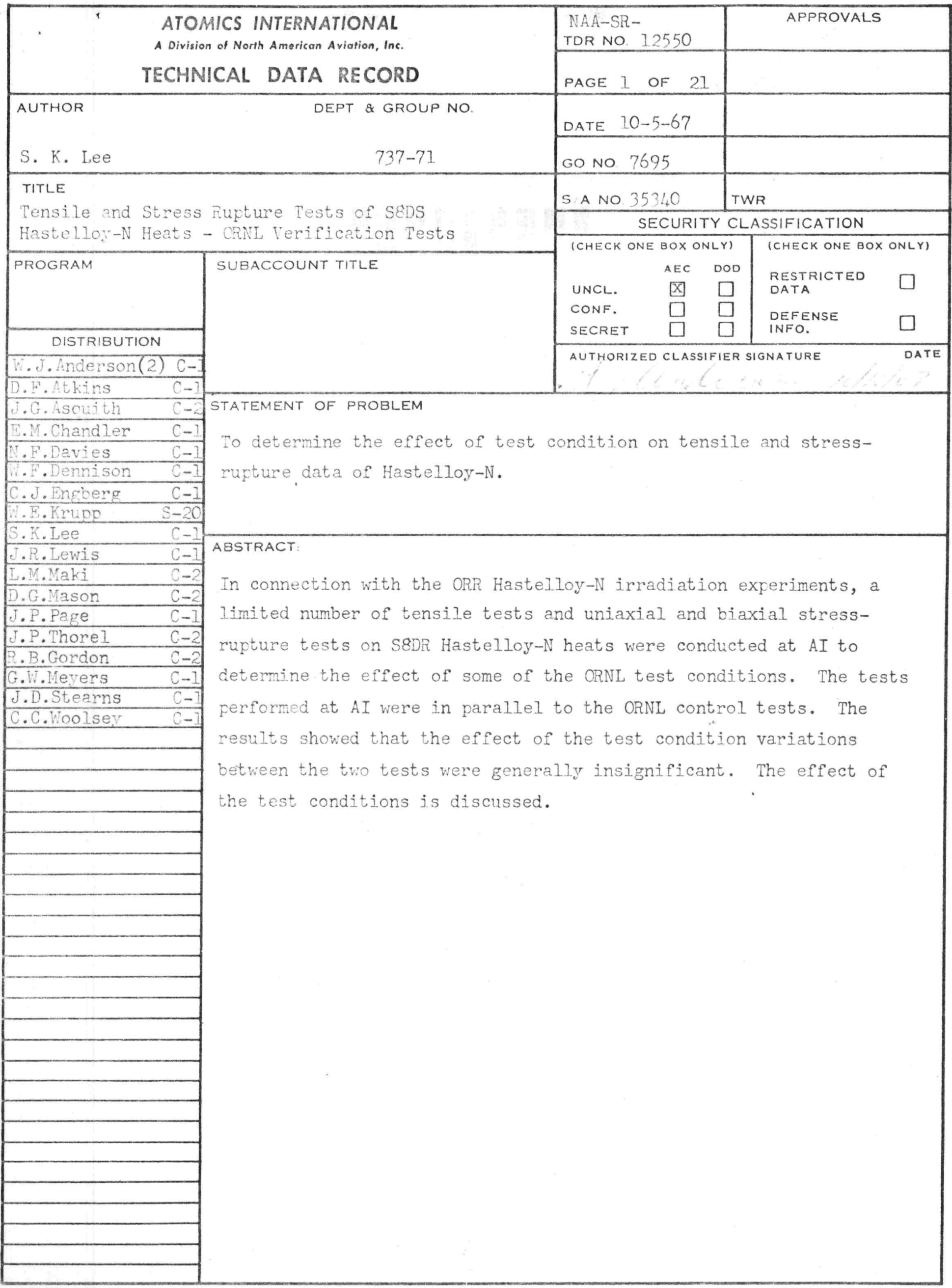


$r$

ATOMICS INTERNATIONAL

A Division of North American Aviation, Inc.
NO. NAA-SK-TDK-12550

DATE October $5, .1967$

PAGE 2 OF 21

\section{INTRODUCTION}

The ORR $-\mathrm{S}-1,-2$, and -3 experiments were conducted to determine the effect of irradiation on the mechanical properties of Hastelloy-N under the SNAP-8 reactor operating conditions. The irradiation effect was derived by comparing test results of identical specimens in the irradiated and unirradiated conditions. Due to simulating the in-pile test conditions and other equipment limitations, standard test procedures and methods were not uniformly followed. Past experience shows that results of mechanical tests are sensitive to test conditions and equipment systems. In order for AI to better interpret the ORNL results and correlate them to available Hastelloy-N data, it was deemed necessary that a limited number of tests parallel to the ORNL control tests be performed at AI. The tests include tensile tests and uniaxial and biaxial stress rupture tests and were designated as "ORNL Verification Tests." 


\begin{tabular}{l} 
NO. $\frac{\text { NAA-SR -TDR }-12550}{\text { DATE }}$ October 5,1967 \\
PAGE 3 OF 21 \\
\hline
\end{tabular}

\section{RESULTS AND DISCUSSIONS}

A. Biaxial Stress-Rupture Tests

The tube specimens for the biaxial stress-rupture tests were produced by AI. They were fabricated of three S8DS Hastelloy-N candidate heats. The specimens were chromized and coated internally. Construction of the specimen

is shown in Figure 1. Dimerisionally, they were $0.56 "$ in diameter, $0.010 "$ in wall thickness, and 4" in length. In these verification tests, three specimens of each heat were tested at three stress levels at $1400^{\circ} \mathrm{F}$. The stresses were selected to obtain stress rupture life to cover the span between 100 to 1000 hours. The results of the tests are given in Table I in comparison with ORNL data. Although stress-rupture lives of the tests are in good agreement (Figure 2), the strains measured in the ORNL tests were consistently higher. Diametral strains in the ORNL data varied from 6.2 to $11.2 \%$, while the AI results ranged only from 3.9 to $6.1 \%$. To determine the discrepancy in ductility between the ORNL and AI data, the effects of some of the known variations in test conditions were investigated.

\section{Temperature Distribution}

In the ORNL control tests, heating was accomplished by sheathed nichrome wires wrapped around the specimens. This produced an axial temperature gradient between the center and ends of the specimens. As a result, failure of the specimens was confined to the central sections of the specimens. Rupture strains of the specimens consequently were free from the effect of end cap and weld restrictions. The AI tests were conducted in long resistance wound furnaces. Under these isothermal conditions, all of the specimens either failed at the welds or near the ends. To ascertain the effect of the temperature distribution on rupture strain, one specimen (No. 5053) which did not fail(because of a fitting leak) was reinserted in the same test rig and tested with an axial temperature gradient of $50^{\circ} \mathrm{F}$ between the central section and the ends. The result was that the specimen failed in the central section and the diametral strain at mpture was found to be higher ( $7 \%$ ) than in any of the other AI biaxial stress-rupture tests. 
Typical distributions of diametrical strain under different heating conditions are shown in Figures 3 to 6.

2. Strain Measurement

Another factor that might have biased the strain results was the diametral strain measurement technique. The ORNL strains were obtained with a micrometer. In the AI tests, a precision profilometer was used. In order to determine the effect of the measuring techniques, the ruptured ORNL unirradiated specimens were returned to AI and subjected to profilometer measurement. The results are compared in Table II. The effect due to measurement technique appears to be negligible.

\section{Test Atmosphere}

Although $\mathrm{He}$ was the in-pile test atmosphere, the ORNL biaxial stressrupture tests were conducted in air with argon as the pressurizing medium with the assumption that the effect of oxidation would be insignificant for chromized and coated Hastelloy-N under the test conditions. Since rupture strains of the specimens tested in air were higher, no investigation was made except to indicate that a discrepancy in atmosphere existed.

The results of the above investigation suggests the discrepancy in ductility was caused by end effect of the specimens rather than a difference in material property.

\section{B. Uniaxial Stress-Rupture Test}

The uniaxial stress-rupture tests were conducted with 1/8" diameter tensile bar specimens. The specimens for the tests were fabricated by ORNL and were not chromized. Dimensions and geometry of the specimens are shown in Figure 6. The only known discrepancy between ORNL and AI tests was the basis for which elongation was computed. The ORNL elongations were based on changes of the overall lengths of the specimens. In the AI tests, they were conputed based on a cne-inch gage length. The results of the verification tests are given in Table III. The rupture life appears to be in good agreement With the ORNL control data, as can be readily seen in Figure 7. No significant difference was apparent arong the heats. The elongation values, however, indicates a significent difference in ductility between heat 6252AC and 5911 AW at $1400^{\circ} \mathrm{F}$ (Table III). The former heat varied from 34\% to 65\% (S/N 3911 

OF 21

excepted; it failed in 10 hours due to overloading) and the range of the latter heat was $23 \%$ to $34 \%$ excluding those whose failures occurred on and outsice the gage marks. The ORNL control data also showed the same behavior. The range of their elongation for $6252 \mathrm{AC}$ was $23 \%$ to $53 \%$ and for $5911 \mathrm{AW}$ was $14 \%$ to $36 \%$.

Vigorous analysis of the difference in rupture ductility is beyond the scope of this work. However, metallographic examination of the specimens with normal failures (excluding failures at and outside gage marks) revealed that it may be related to the degree of microsegregation banding of the specimens. The specimens from heat $6252 \mathrm{AC}$ had more pronounced segregation banding as shown in Figure 8.

The segregation banding appears to retard intergranular crack propagation. This retardation of crack propagation might have resulted in the redistribution of some of the stresses to the grain and caused distortion that contributed to the bulk of the deformation. Furthermore, chemical segregation would deplete the matrix material of alloying constituent and possibly make it more ductile. Other metallographic evidence indicated that there was some difference in the mode of fracture. Heat $6252 \mathrm{AC}$ specimens failed with a limited amount of subcracking and the cracks were spheroidized. Heat $5911 \mathrm{AW}$, on the other hand, failed with profuse wedge shape subcracking. The difference in subcracking phenomena is shown in Figure 9.

\section{Tensile Test}

The tensile test specimens were identical to those used in the uniaxial stress-rupture test (see Figure 6). Deviations in the tensile tests between AI and CKNL was the method of deriving strain values. The ORNL tensile test elongation data were obtained by measuring the load-extension diagrams of the Instron universal testing machine. The extension corresponding to the maximum and the mupture loads were regarded as uniform and total elongations, respectively. In addition to obtaining similar data, one inch gage marks were placed on the verification test specimens to determine elongation. The results of the verification tensile tests are shown in Table IV and the ORNL results in Table $\mathrm{V}$. At $1400^{\circ} \mathrm{F}$, the data are in fair agreement. The ductility values are rather scattered and they were too few to denote any significant 


\section{ATOMICS INTERNATIONAL}

OF

21

deviation. The $1200^{\circ} \mathrm{F}$ verification tests were affected by failure at the gage marks. It indicated the increase notch sensitivity of the material at the lower test temperature. The gage mark failure was also responsible for the lower values in some of verification test data. The verification tensile tests showed that the total elongation values obtained from the load diagrams were higher than those obtained by actual gage length measurements. This is probably due to the elastic strain and machine compliance which are included in the load diagram values.

It should also be noted in the data of both these verification tests and in the ORNL tests that the total elongations at $1200^{\circ} \mathrm{F}$ were primarily uniform and largely nonuniform at $1400^{\circ} \mathrm{F}$ according to the Instron load-extension diagrams. 
NO. NAA-SR-TDR- 12550

DATE October 5, 1967

PAGE OF

\section{CONCLUSIONS AND RECOMMENDATIONS}

General agreement in the results of the AI verification tests and ORNL control tests indicates that the effect of test condition deviations are insignificant. The higher rupture strain range of the ORNL biaxial stress rupture tests should be accepted because the verification test strains were influenced by abnormal failures. However, the results should serve to indicate that diametral rupture strains are lower for end sections compared to central section of fuel cladding.

The verification tensile test results show that elongation values obtained from the Instron load diagram. Hence, for direct comparison of ductility data, the ORNL elongation should be reduced by $25 \%$.

The results of AI verification uniaxial stress mpture tests generally agreed with those of the ORNL control tests. Both data showed that heat $6252 \mathrm{AC}$ was more ductile than heat 5911 AW. It was not established whether this variation in ductility was caused by the difference in heat of the material or by their process conditions. The fact that the same stress range was covered by specimens from both heats indicates the effect was probably structural rather than caused by test conditions. Difference in the mode of failure between specimens failed with high and low strain may represent the structural influence on controlling creep mechanisms. It is recommended that the specimens be rigorously re-examined. Microprobe analysis and X-ray diffraction should be performed to determine the nature of the segregation bending and electron microscopy should be conducted to determine creep mechenisms. The structural effect, if verified, may be exploited to improve the mechanical properties of Hastelloy-N. 


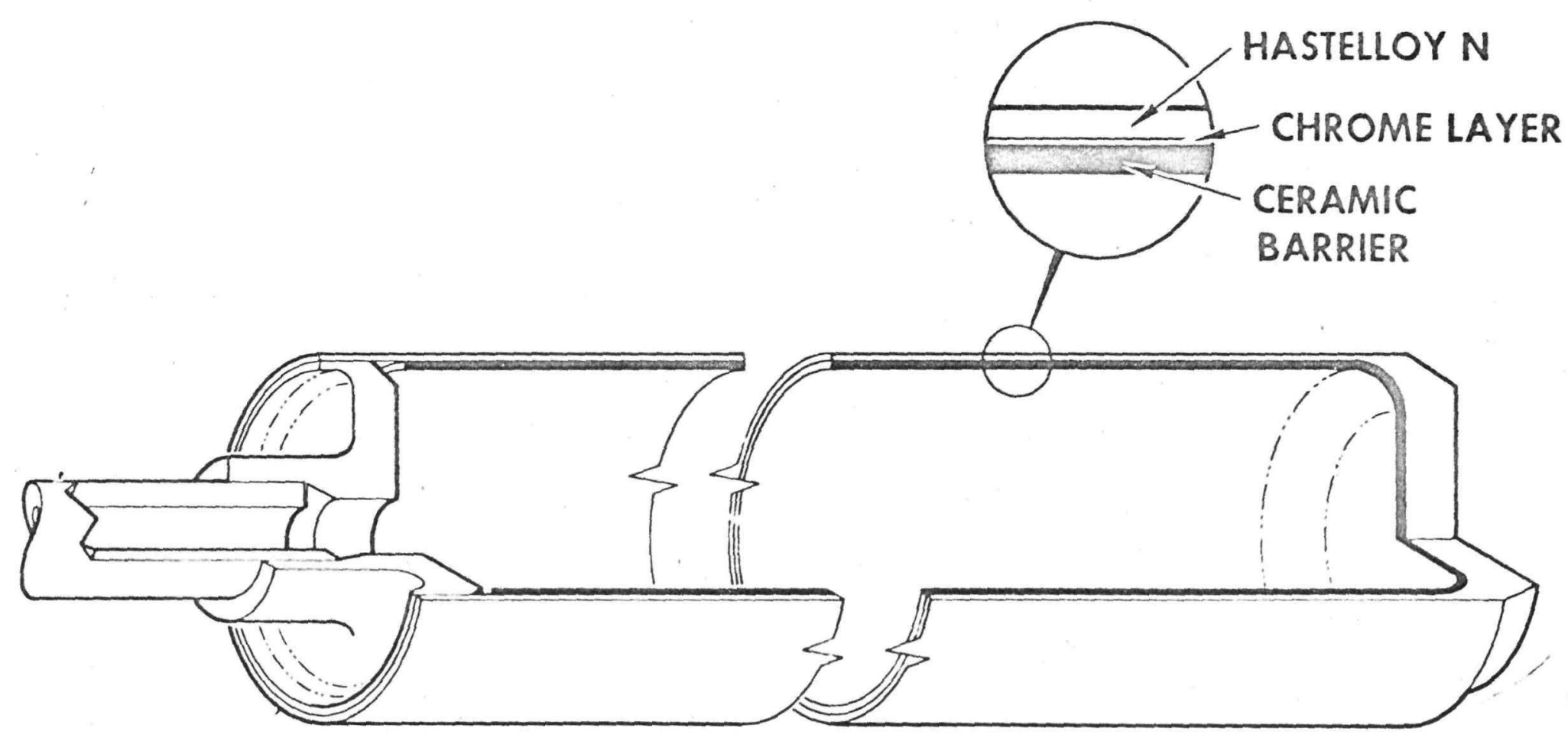

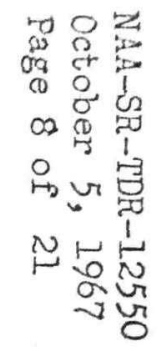

FIGURE 1. Construction of Biaxial Stress Rupture Specimen. 
TABLE 3.

COMPARISON OF AI AND ORNL $1400^{\circ} \mathrm{F}$ UNIRRADIATED BIAXIAL STRESS RUPTURE TEST RESULTS

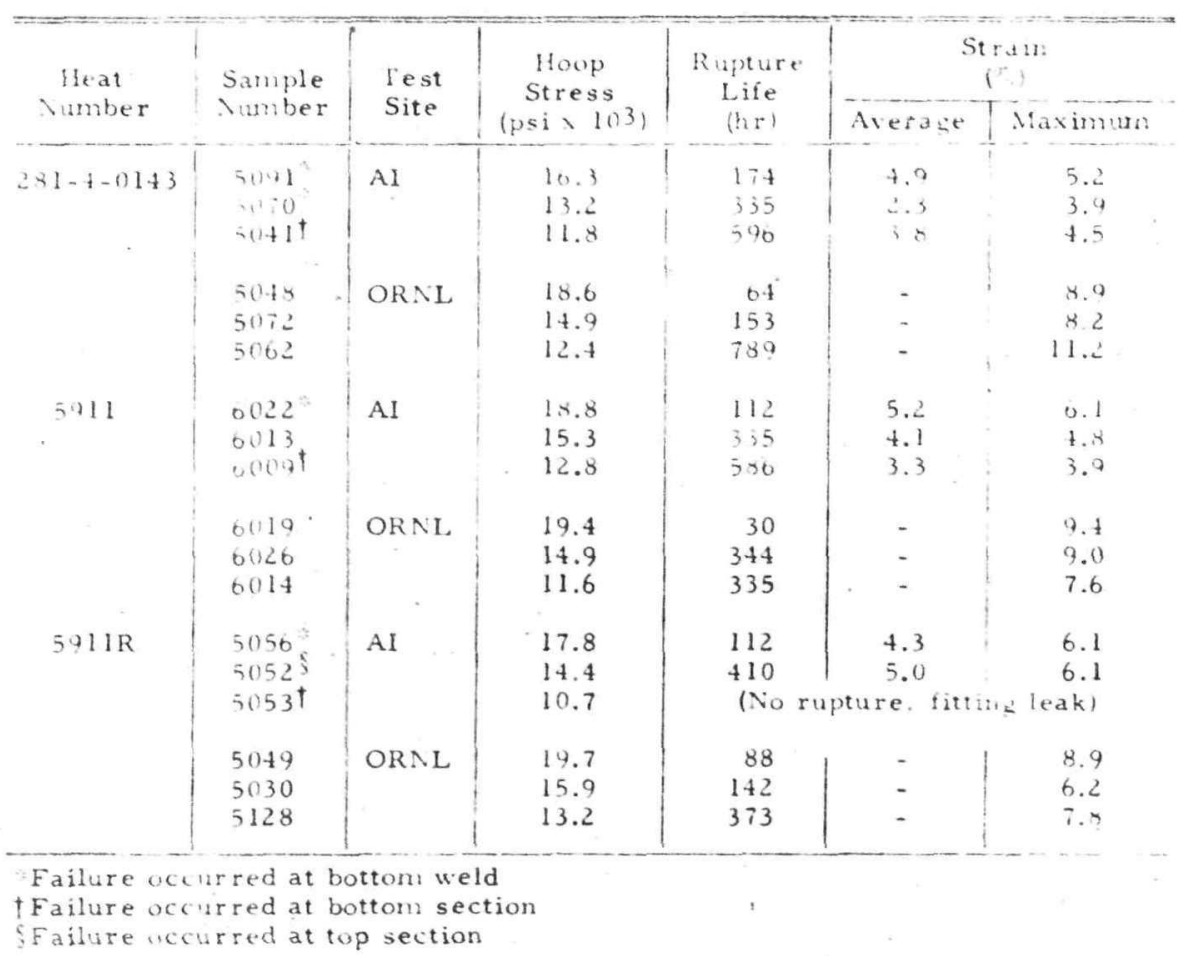

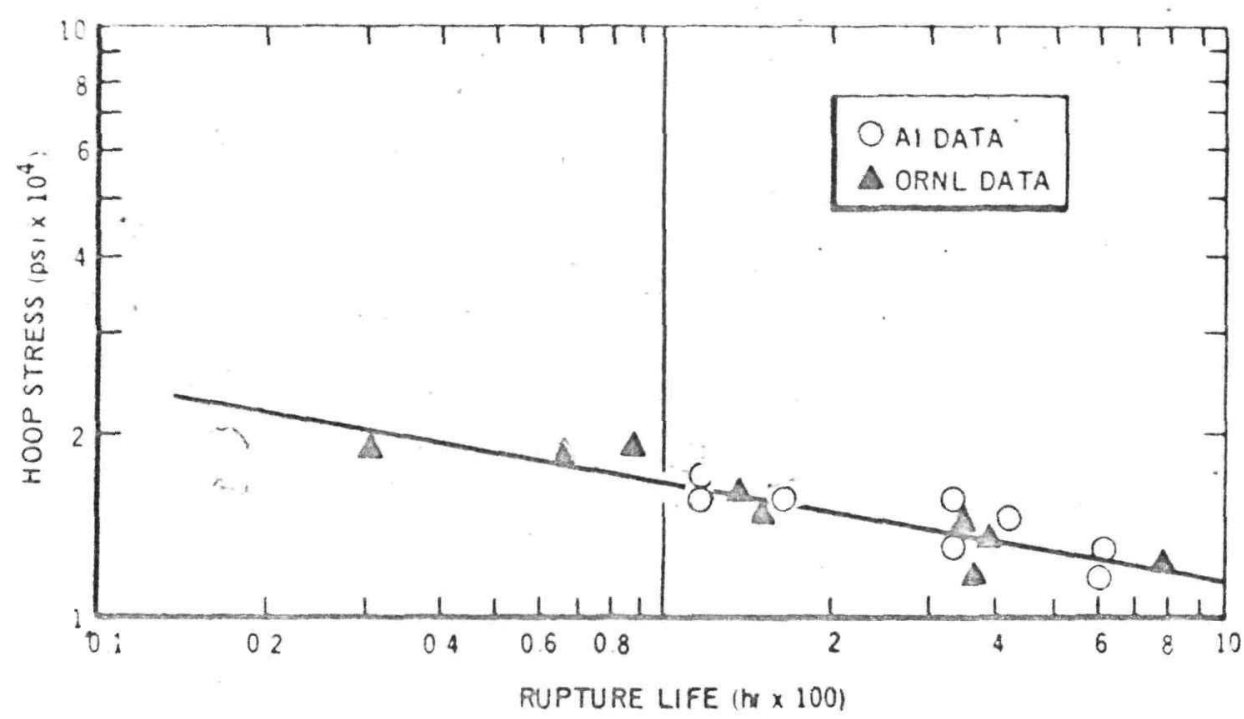

Figure 2. Comparison of ORNL and AI Biaxial Stress Rupture Test Results at $1400^{\circ} \mathrm{F}$ on SNAP 8 Cladding 
NAA-SR-TDR- 12550

Page 10 of 21

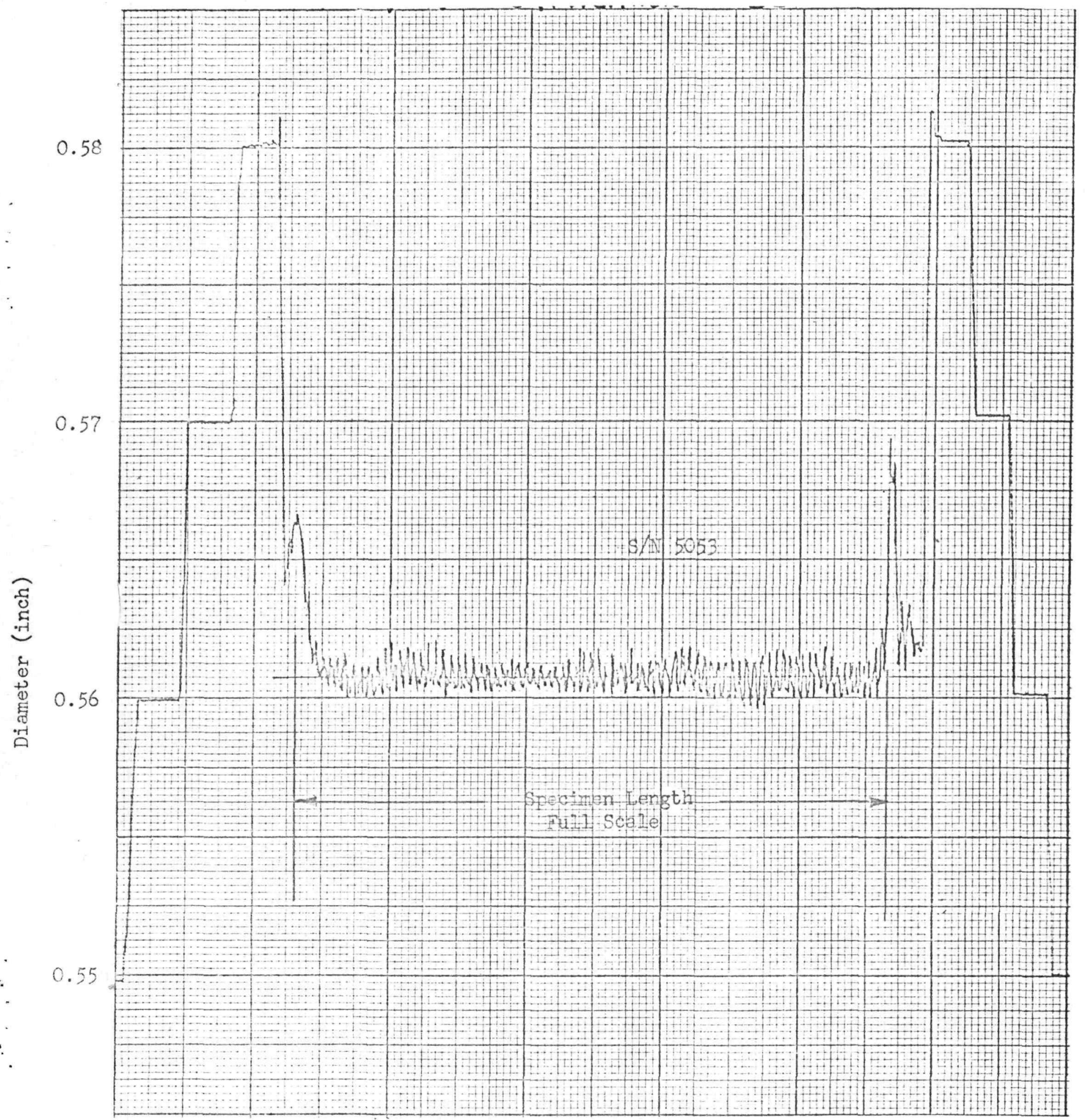

FIGURE 3. Tutical Diameter Profile of Biaxial Stress Rupture Specimens Before Test 
NAA-SR -TDR-12550

October 5, 1967

Page 11 of 21

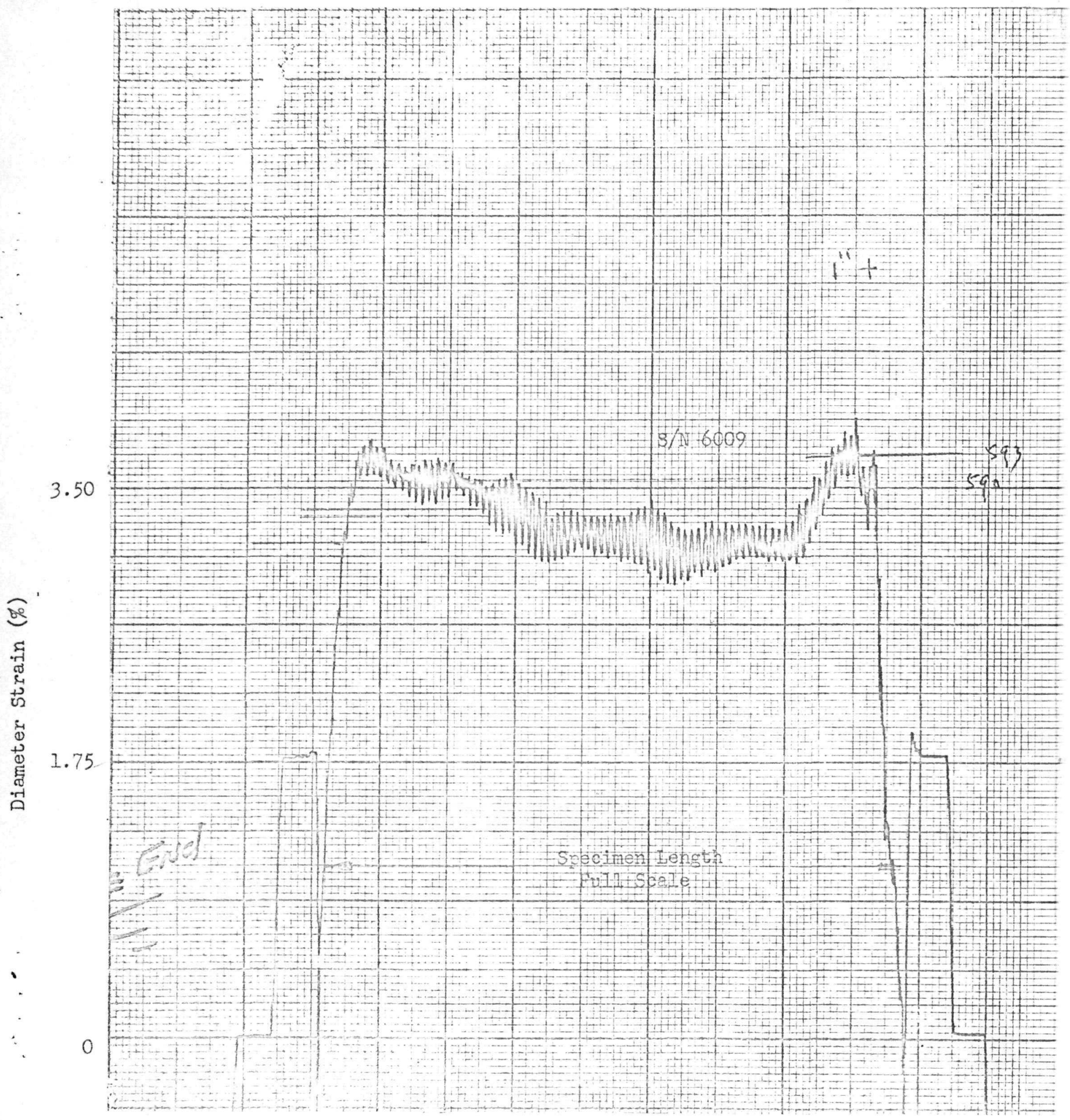

PIGURE 4. Typical Diaratric Strain Distribution of Biaxial Stress Rurture Specimens Heated in Marshall Furnace with Uniform Temperature 
NAA-SR-TDR-12550

October 5, 1967

Page 12 of 21



FIGURE 5. Diametric Strain Distribution of Biaxial Stress Rupture Specimen Heated in Marshall Furnace with Temperature Gradient of $50^{\circ} \mathrm{F}$ Between the Center and Ends of Specimen 
NAA-SR-TDR-12550

October 5, 1967

Page 13 of 21

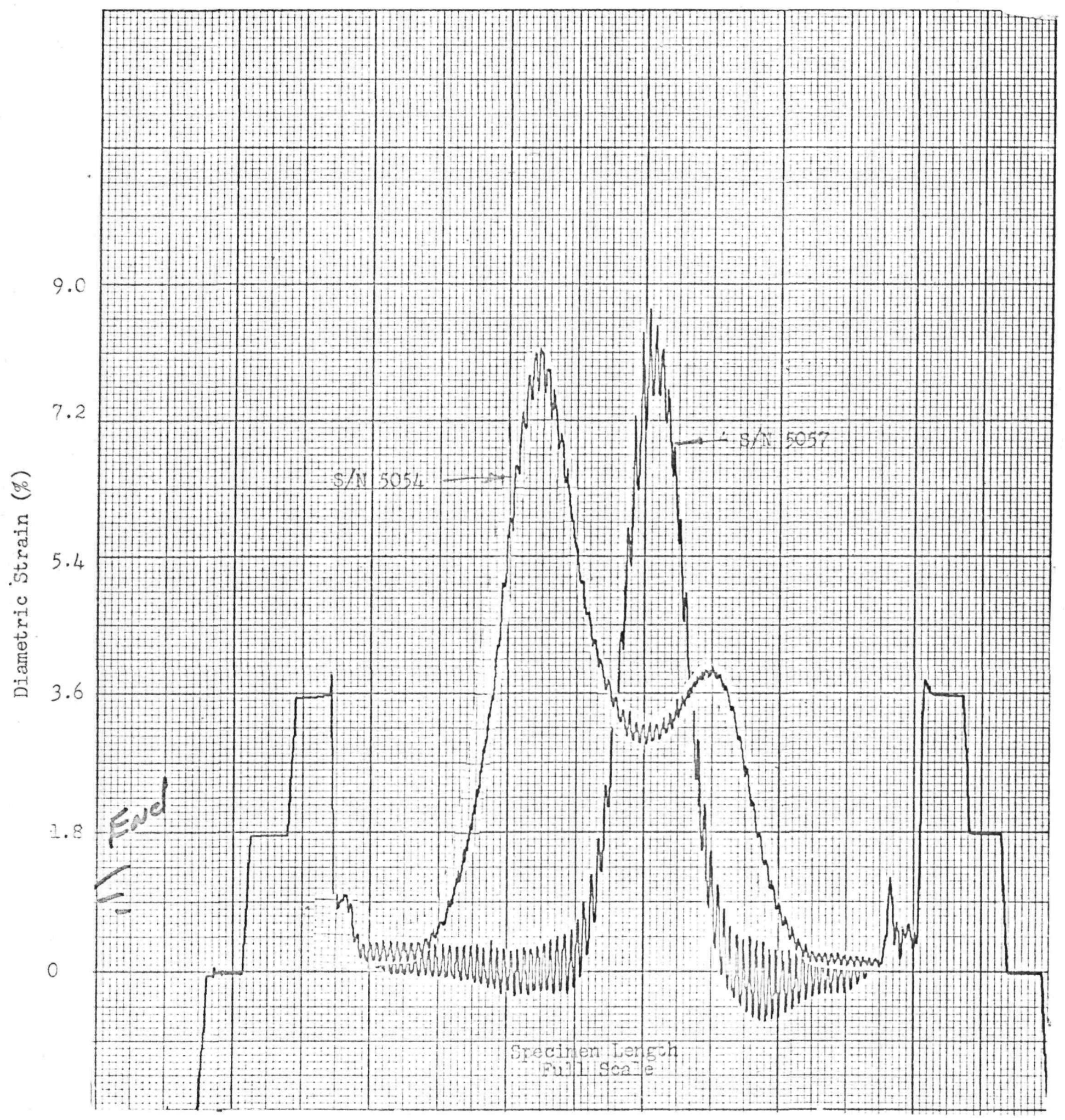

FIGURE 6. Typical Diametric Strain Distribution of ORNL Biaxial Stress Rupture Test Specimen Heated by Nichrome Wire and with Axial Temperature Gradient of $200^{\circ}$ to $300^{\circ} \mathrm{F}$ Between the Center and Ends of Specimen 
ATOMICS INTERNATIONAL

A Division of North American Aviation, Inc.

$\begin{array}{ll}\text { NO. } & \text { NAA-SR-TDR-12550 } \\ \text { DATE } & \text { October } 5,1967 \\ \text { PAGE } 14 \text { OF } 21\end{array}$

TABLE II

COMPARISON OF RUPTURE STRATN, MEASURED BY PROFILONETER AND MICROMETER

Profilometer Micrometer

\begin{tabular}{|c|c|c|}
\hline Specimen No. & $(\%)$ & $(\%)$ \\
\hline 5069 & 17.2 & 17.2 \\
\hline 5057 & 6.89 & 6.7 \\
\hline 5097 & 8.07 & 7.7 \\
\hline 5068 & 4.77 & 4.6 \\
\hline 5098 & 9.69 & 9.6 \\
\hline 5048 & 7.56 & 8.9 \\
\hline 5072 & 8.17 & 8.2 \\
\hline 5062 & 10.27 & 11.1 \\
\hline 5078 & 10.75 & 10.6 \\
\hline 6025 & 6.82 & 8.4 \\
\hline 6029 & 3.35 & 3.9 \\
\hline 6019 & 9.4 & 9.4 \\
\hline 6018 & 6.73 & 6.4 \\
\hline 6026 & 8.75 & 9.0 \\
\hline 6014 & 8.78 & 7.6 \\
\hline 6031 & 4.56 & 4.6 \\
\hline 5127R & 8.76 & 9.1 \\
\hline $5126 \mathrm{R}$ & 4.97 & $4 \cdot 4$ \\
\hline $5057 \mathrm{R}$ & 8.09 & 8.2 \\
\hline 5050R & 9.22 & 8.2 \\
\hline $5049 \mathrm{R}$ & 8.11 & 8.9 \\
\hline $5038 \mathrm{R}$ & 7.90 & 7.8 \\
\hline $5130 R$ & 7.53 & 6.2 \\
\hline $5128 \mathrm{R}$ & 7.99 & 7.8 \\
\hline $5123 R$ & 7.24 & 6.8 \\
\hline $5054 \mathrm{R}$ & 7.76 & 7.7 \\
\hline
\end{tabular}




\begin{tabular}{|c|c|}
\hline & NAA-SR-TDR-12550 \\
\hline DATE. & October 5, 1967 \\
\hline PAGE & 15 OF 21 \\
\hline
\end{tabular}

TABLE III

VERIFICATION UNIAXIAL STRESS RUPTURE TEST RESULTS

\begin{tabular}{|c|c|c|c|c|c|c|c|}
\hline $\begin{array}{l}\text { Heat } \\
\text { Number } \\
\end{array}$ & $\begin{array}{l}\text { Specimen } \\
\text { Number } \\
\end{array}$ & $\begin{array}{l}\text { Test } \\
\text { Temp. } \\
\left({ }^{\circ F}\right)\end{array}$ & $\begin{array}{l}\text { Stress } \\
\text { (psi) }\end{array}$ & $\begin{array}{l}\text { Rupture } \\
\text { Life } \\
\text { (hr) } \\
\end{array}$ & $\frac{\begin{array}{c}\text { Total } \\
\text { Elongation } \\
\left(\begin{array}{c}\infty \\
\mu\end{array}\right)\end{array}}{}$ & $\begin{array}{c}\text { Reduction } \\
\text { in Area } \\
\left(\begin{array}{l}\% \\
\%\end{array}\right) \\
\end{array}$ & $\begin{array}{l}\text { Minimum } \\
\text { Creep Rate } \\
\text { (in./in./hr }\end{array}$ \\
\hline \multirow[t]{16}{*}{ 5911AW } & 3529 & 1400 & 20,400 & 138.9 & 23.0 & 22.7 & $1.2 \times 10^{-3}$ \\
\hline & $3534 *$ & 1400 & 20,700 & 122.8 & 25.0 & 24.4 & $2.5 \times 10^{-3}$ \\
\hline & 3536 & 1300 & 25,700 & 509 & 22.0 & 18.7 & $2.8 \times 10^{-4}$ \\
\hline & 3541 & 1400 & 13,300 & 733 & 23 & 15.5 & $2.0 \times 10^{-4}$ \\
\hline & $3542^{2} \cdots$ & 1400 & 13,700 & 349.3 & 3 & 0 & $8.2 \times 10^{-5}$ \\
\hline & $3545 * *$ & 1300 & 18,800 & 1664.8 & 18 & 6.5 & $5.3 \times 10^{-5}$ \\
\hline & $3538 \div-\div$ & $\because 1400$ & 11,200 & 1222 & 16 & 11.0 & $7.7 \times 10^{-5}$ \\
\hline & $3540 \div-$. & 1400 & 11,600 & 1596 & 20.0 & 19.0 & $9.1 \times 10^{-5}$ \\
\hline & 4281 & 1200 & 50,100 & 45.6 & 17.0 & 15.3 & $9.9 \times 10^{-4}$ \\
\hline & 4284 & 1200 & 35,000 & 448.2 & 11.0 & 13.9 & $9.1 \times 10^{-5}$ \\
\hline & $4280 \div$ & 1400 & 20,000 & 94.4 & 18.0 & 15.3 & $1.7 \times 10^{-3}$ \\
\hline & $4287 \div-x$ & 1400 & 13,000 & 857.6 & 24.0 & 19.7 & $1.7 \times 10^{-4}$ \\
\hline & 4285 & 1400 & 11,600 & 1569.5 & 34.0 & 26.0 & $9.9 \times 10^{-5}$ \\
\hline & 4286 & 1400 & 11,400 & 1829 & 35.0 & 28.5 & $1.6 \times 10^{-4}$ \\
\hline & $4282 * *$ & 1400 & 10,200 & 2104 & 19 & 12.5 & $9.0 \times 10^{-5}$ \\
\hline & 4283 & 1400 & 10,000 & 2435 & 23 & $25 \cdot 4$ & $6.5 \times 10^{-5}$ \\
\hline \multirow[t]{8}{*}{$6252 \mathrm{AC}$} & 3912 & 1200 & 50,000 & 52.9 & 13.0 & 11.0 & $1.2 \times 10^{-3}$ \\
\hline & 3915 & 1200 & 35,000 & 821.2 & 22 & 18.3 & $1.1 \times 10^{-4}$ \\
\hline & 3911 & 1400 & 33,300 & 10.8 & 23 & 22.7 & - \\
\hline & 3918 & 1400 & 13,000 & 941.8 & 65 & 46.0 & $2.5 \times 10^{-4}$ \\
\hline & 3916 & 1400 & 11,600 & 1415 & 54 & 35.5 & $1.6 \times 10^{-4}$ \\
\hline & 3917 & 1400 & 12,000 & 1572 & 63 & 36.0 & $2.2 \times 10^{-4}$ \\
\hline & 3913 & 1400 & 10,000 & 2504 & 50 & 36.0 & $1.0 \times 10^{-4}$ \\
\hline & $39: 24$ & 1400 & 10,000 & 2135 & 34 & 41.0 & $1.0 \times 10^{-4}$ \\
\hline
\end{tabular}

*Broke outside gage length

* Broke on gage mark

*

*** Specimen failed due to equipment malfunction 


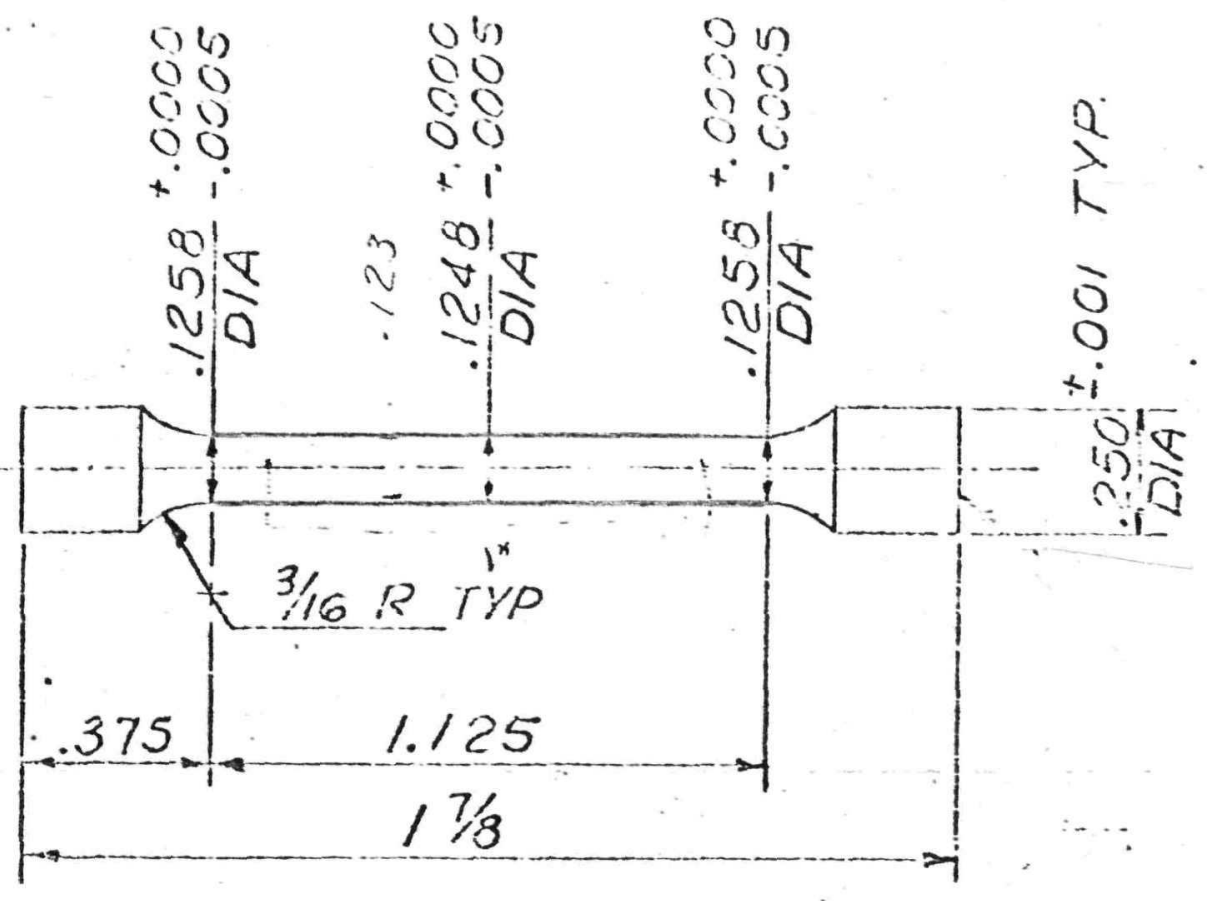

FIGURE 7. Uniaxial Stress Rupture and Tensile Test Specimen 
FIGURE 8

\section{UNIAXIAL STRESS RUPTURE PROPERTIES OF HASTELLOY-N BAR AT $1400^{\circ} \mathrm{F}$}

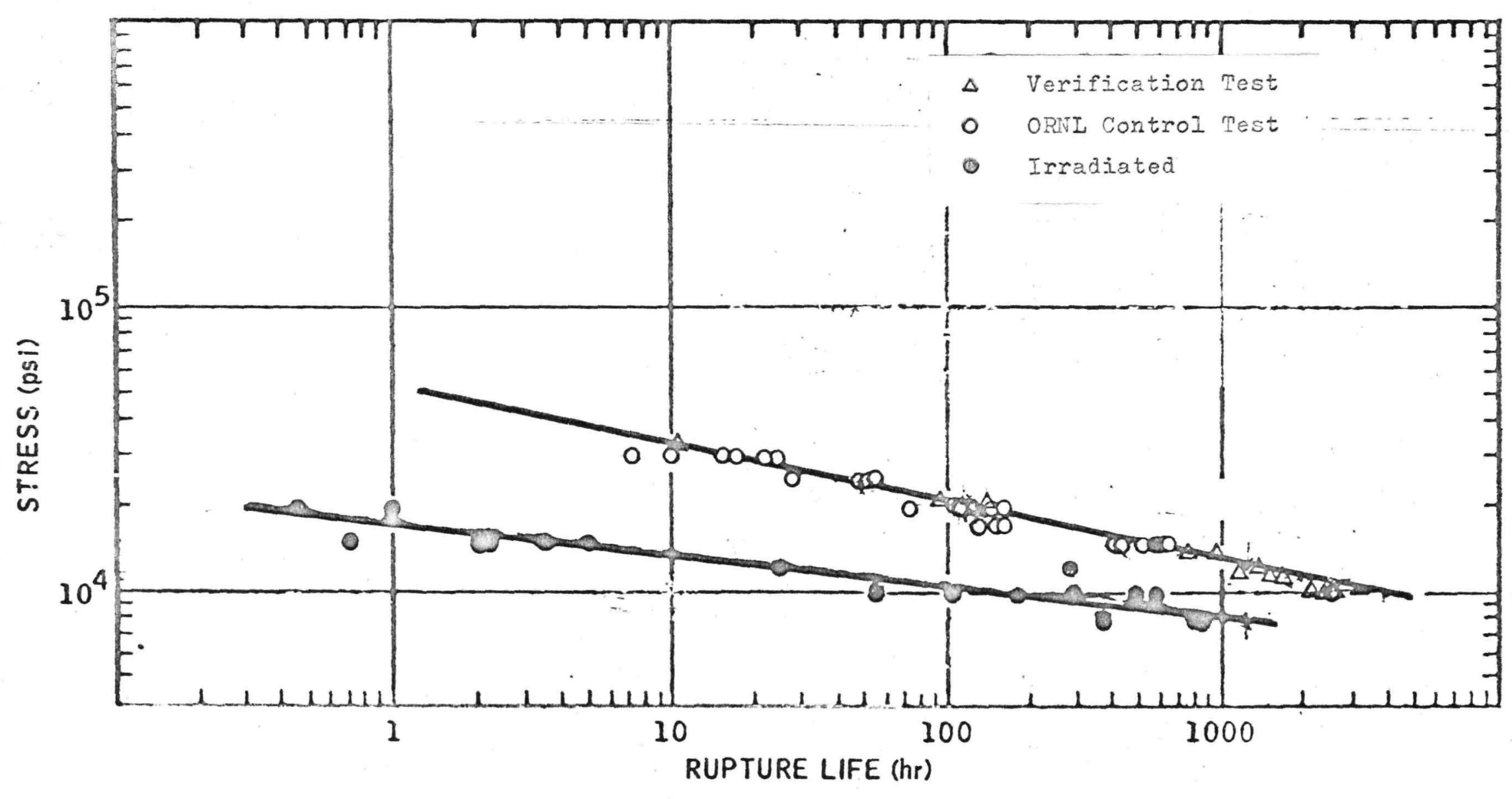




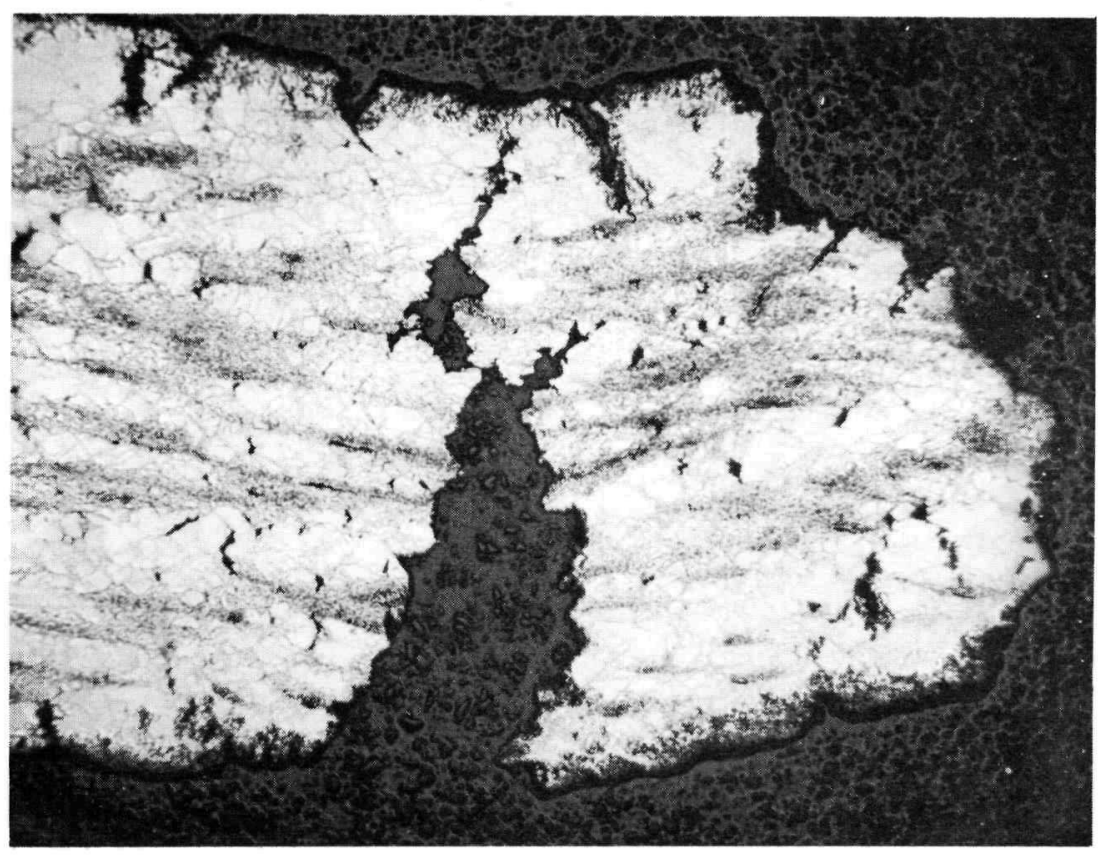

Fracture Area of S/N 3916

Heat $6252 \mathrm{AC}$

$\begin{array}{lll}\text { Temperature }-1400^{\circ} \mathrm{F} & \text { Stress } & -11,600 \\ \text { Rupture Life }-1415 \mathrm{hrs} & \text { Elongation }-50 \%\end{array}$

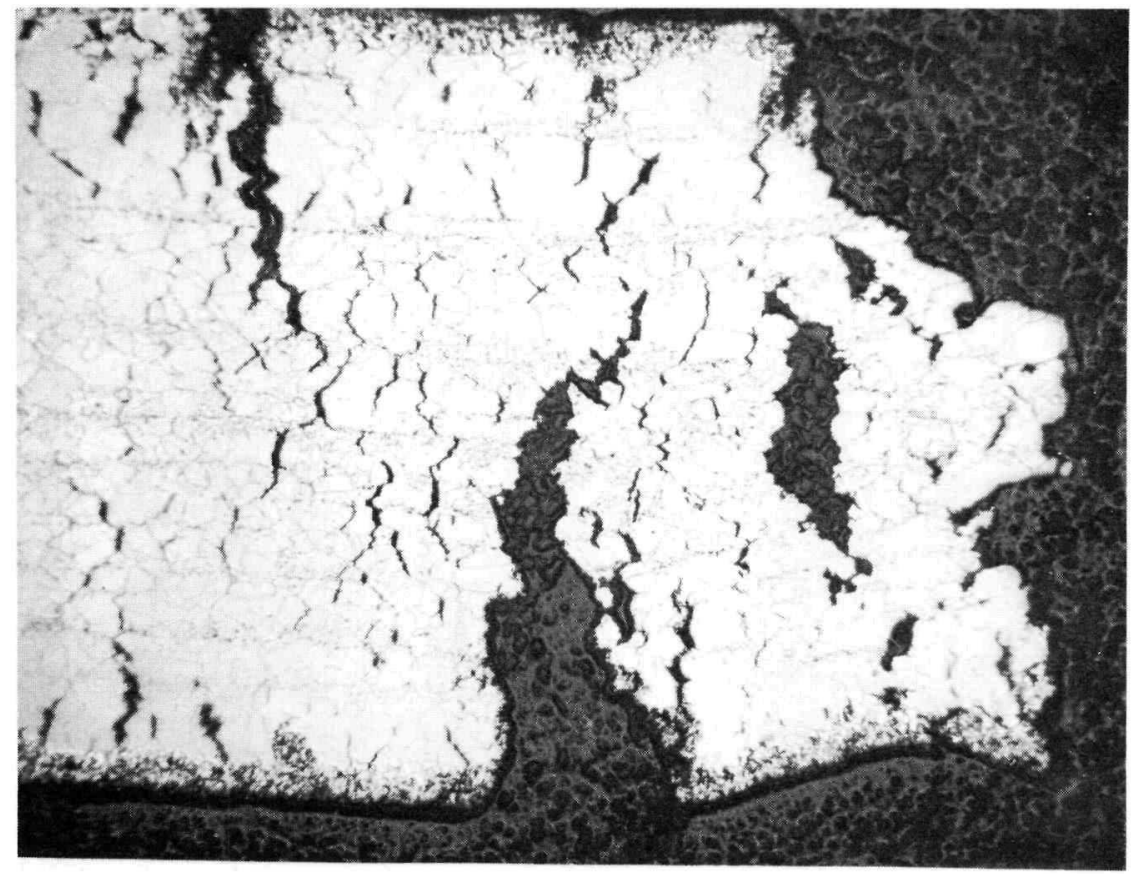

Fracture Area of S/N 4283

Temperature $-1400^{\circ} \mathrm{F}$

Heat 5911 AW

Rupture Life - 2435

Stress - 10,000

Elongation - 23\%

FIGURE 9. Comparison of Microsegregation Between Heats $5252 \mathrm{AC}$ and $5911 \mathrm{AW}$ (40X) 
NAA-SR-TDR-12550

October 5, 1967

Page 19 of 21

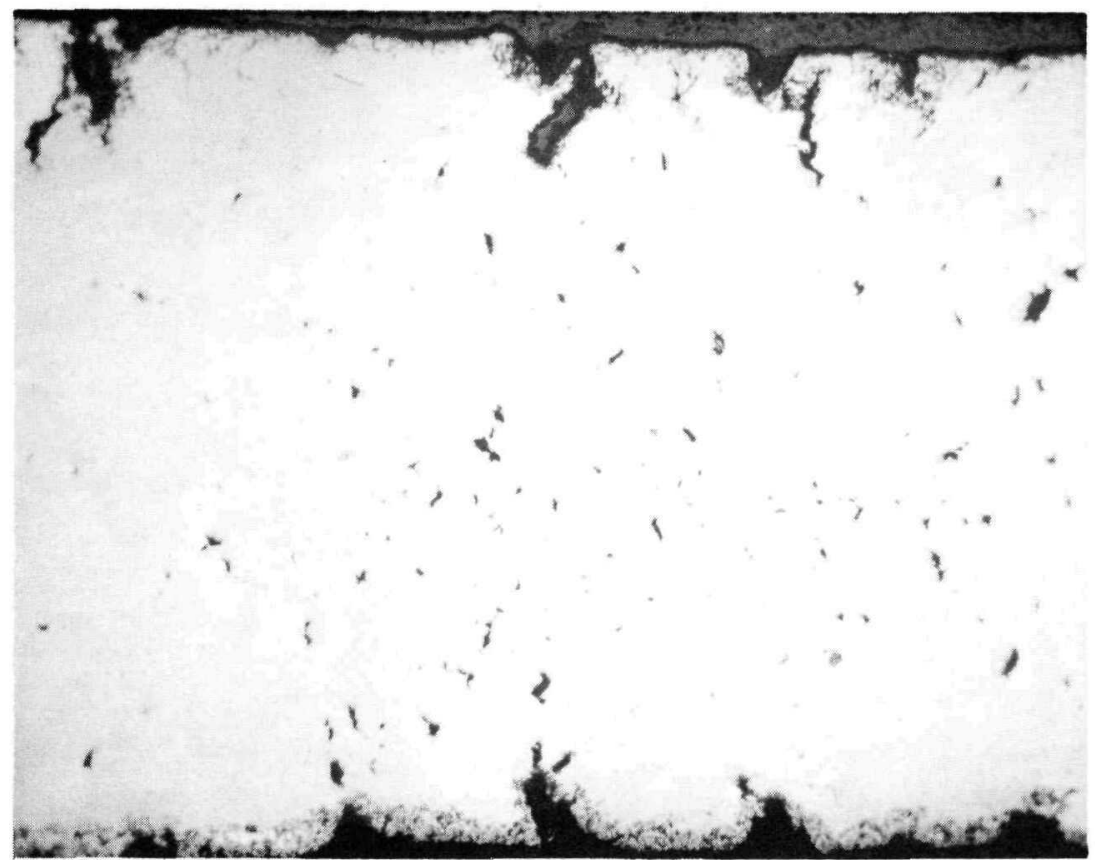

Limited Intergranular Cracking Near Fracture Zone. Cracks are spheroidized for Heat $6252 \mathrm{AC}$.

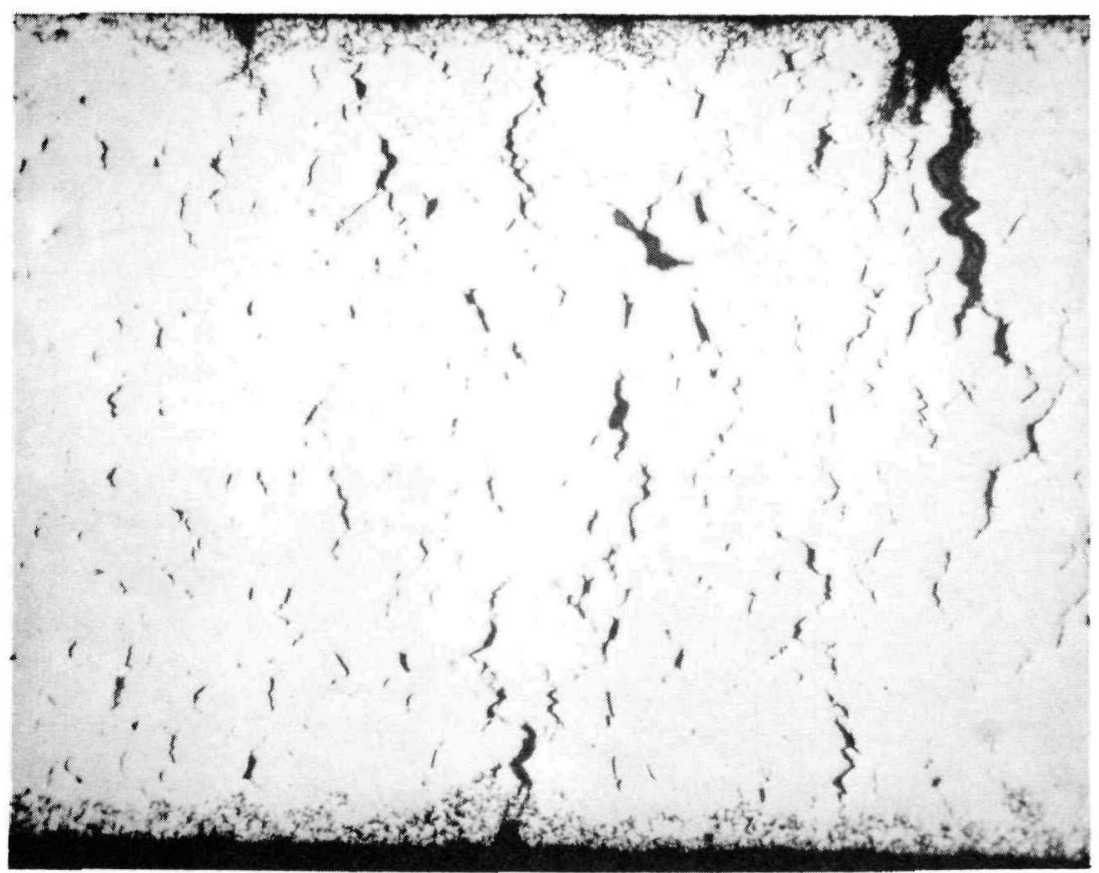

Profused Intergranular Cracking Near Fracture Zone. Cracks are Wedge Shape for Heat 5911 AW.

FIGURE 10. Comparison of Stress Rupture Specimens Between Heats $6252 \mathrm{AC}$ and 5911 AW (40X). 


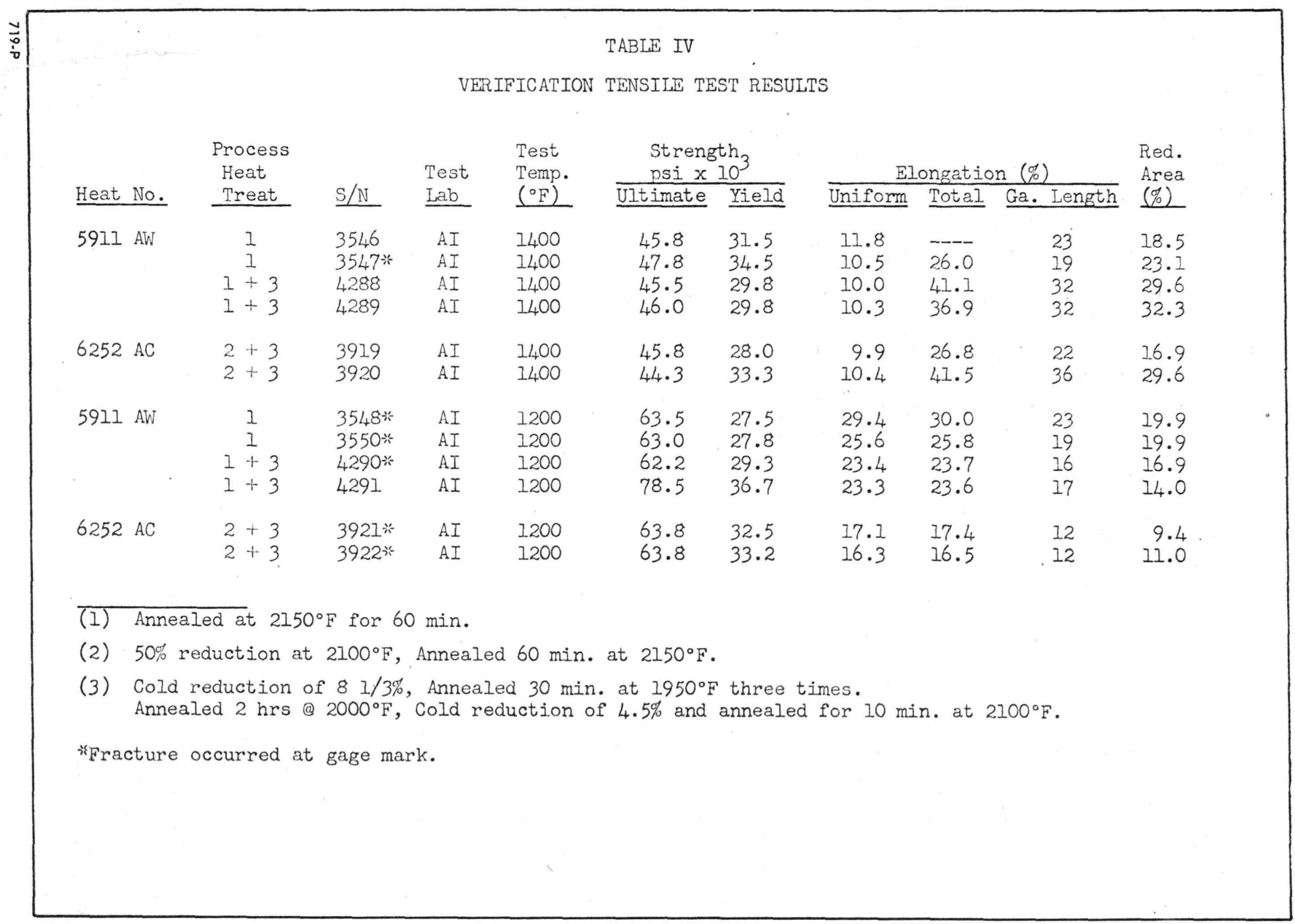

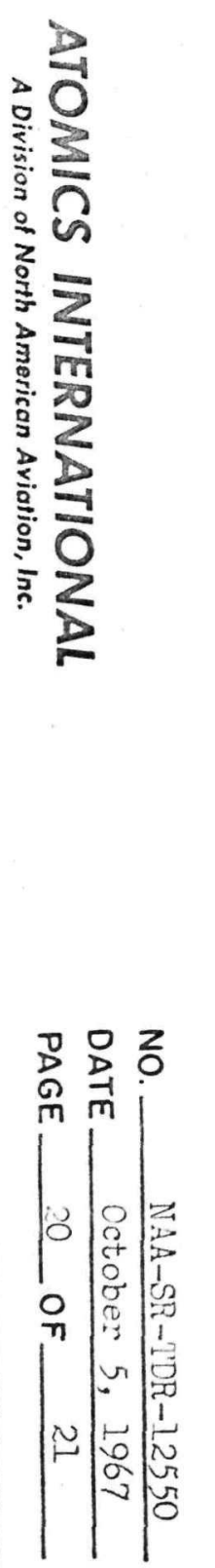




\begin{tabular}{|c|c|c|c|c|c|c|c|c|c|}
\hline \multirow[b]{2}{*}{$\begin{array}{l}\text { Heat } \\
\text { Number }\end{array}$} & \multicolumn{8}{|c|}{$\begin{array}{c}\text { TABIE } V \\
\text { ORNL CONTROL TENSILE TESTS RESULTS }\end{array}$} & \multirow[b]{2}{*}{$\begin{array}{l}\text { Reduction } \\
\text { in Area } \\
(\%)\end{array}$} \\
\hline & $\begin{array}{l}\text { Specimen } \\
\text { Number }\end{array}$ & $\begin{array}{l}\text { Heat } \\
\text { Treat } \\
\text { Process } \\
\end{array}$ & $\begin{array}{l}\text { Pre- } \\
\text { Test } \\
\text { Aging* }\end{array}$ & $\begin{array}{l}\text { Test } \\
\text { Temp. } \\
\left({ }^{\circ} \mathrm{F}\right) \\
\end{array}$ & $\begin{array}{l}\text { Ultimate } \\
\text { Strength } \\
\text { (psi) } \\
\end{array}$ & $\begin{array}{l}\text { Yield } \\
\text { Strength } \\
\text { (psi) } \\
\end{array}$ & $\begin{array}{l}\text { Uniform } \\
\text { Elongation } \\
\quad(\%) \\
\end{array}$ & $\begin{array}{l}\text { Total } \\
\text { Elongation } \\
(\%) \\
\end{array}$ & \\
\hline \multirow[t]{7}{*}{$5911 \mathrm{AW}$} & 3113 & 1 & B & 1020 & 87,800 & 32,600 & 57.1 & 58.2 & 41.6 \\
\hline & 3117 & 1 & A & 1020 & 96,500 & 31,400 & 61.7 & 64.8 & 47.5 \\
\hline & 3114 & 1 & B & 1110 & 65,200 & 35,400 & 22.5 & 23.5 & 23.2 \\
\hline & 3119 & 1 & A & 1110 & & & & & \\
\hline & 3108 & 1 & A & 1200 & 77,700 & 29,700 & 39.8 & 40.8 & 35.3 \\
\hline & 31.06 & $3 \mathrm{~A}$ & A & 1200 & 70,800 & 26,400 & 43.2 & 43.4 & 36.6 \\
\hline & 2959 & 3 & A & 1200 & 76,600 & 34,300 & 29.6 & 30.3 & 25.7 \\
\hline $5911 \mathrm{TH}$ & 3103 & 1 & A & 1200 & 74,300 & 29,200 & 41.1 & 42.7 & 33.5 \\
\hline \multirow[t]{4}{*}{$5911 \mathrm{AW}$} & 3121 & 1 & A & 1400 & 50,900 & 28,900 & 12.5 & 25.9 & $27.3^{\circ}$ \\
\hline & 3109 & 1 & B & 1400 & 47,700 & 32,200 & 8.0 & 13.4 & 14.4 \\
\hline & 3115 & 1 & B & 1400 & 51,100 & 31,700 & 12.8 & 16.6 & 13.1 \\
\hline & 2854 & $3 \mathrm{~A}$ & B & 1400 & 46,700 & 31,700 & 8.0 & 13.6 & 12.5 \\
\hline$\downarrow$ & 2953 & .3 & B & 1400 & 45,800 & 32,200 & 8.2 & 22.9 & 22.1 \\
\hline $5911 \mathrm{TH}$ & 3091 & 1 & B & 1400 & 47,800 & 32,400 & 7.7 & 16.2 & 13.9 \\
\hline \multirow{5}{*}{$6252 \mathrm{AC}$} & 2919 & 2 & $\mathrm{~A}$ & 1200 & 66,600 & 34,000 & 15.1 & 15.4 & 17.4 \\
\hline & 2948 & $2+3$ & A & 1200 & 73,500 & 37,500 & 21.6 & 21.9 & 19.1 \\
\hline & 2921 & 2 & B & 1400 & 45,000 & 32,000 & 6.1 & 8.6 & 7.3 \\
\hline & 3130 & $2 \mathrm{~A}$ & B & $1400^{\circ}$ & 46,800 & 25,700 & 7.7 & 10.6 & 10.1 \\
\hline & 2944 & $2+3$ & B & 1400 & 44,700 & 33,500 & 8.7 & 20.2 & 17.6 \\
\hline \multicolumn{3}{|c|}{ FPre-test aging treatments: } & \multicolumn{5}{|c|}{$\begin{array}{l}\mathrm{A}=1080 \mathrm{hrs} \text { at } 1200^{\circ} \mathrm{F} \\
\mathrm{B}=1080 \mathrm{hrs} \text { at } 1400^{\circ} \mathrm{F}\end{array}$} & & \\
\hline
\end{tabular}

